\title{
Analysis Of Spatial Inequality In Development In The South- South Region, Nigeria: A Factor Analytical Approach
}

\author{
Innocent I. Weje and Samuel Bankole Arokoyu \\ Department of Geography \& Environmental Management, Faculty of Social Sciences, University of Port \\ Harcourt, Port Harcourt, Rivers State, Nigeria
}

\begin{abstract}
Spatial inequality is not only a mark of underdevelopment and a stumbling block to true human welfare. It is an important tool in the creation of privileged groups of individuals and places on one hand, and deprived groups on the other, and may in turn breed primordial loyalty and social conflict. Using selected health and education variables as indicators of development, three orthogonal factors that accounted for 54.36 per cent of the variation in the original variables were extracted. On rotation, three factors of health, literacy, and education were implicated as key to the explanation of the variation in development in the south-south region of Nigeria. The study advocates for effective regional development hinged on incorporating the disadvantaged areas (rural centers) into the privileged areas (urban centers) through increased information flow and the provision of socio-economic facilities through the process of integrated rural development planning.
\end{abstract}

Keywords: Spatial Inequality, Integrated Rural Development, Regional Dualism, South-south Region, Socioeconomic Facilities.

\section{Introduction}

It is widely agreed that preservation of human dignity and fulfillment of basic needs are the foremost duties of every society. Again, if all men have a right based on inviolability, why are some people and places denied basic means of survival on account of spatial discrimination in the distribution of societal resources? Admittedly, spatial inequality exists everywhere irrespective of level of development or ideological disposition, inequality is however, observed to be a phenomenon in developing countries (Bhagwati, 1971).

Spatial inequality is not only a mark of underdevelopment (Mabogunje,1980), it is a stumbling block to true human welfare to the extent that, it creates privileged groups of individuals on one hand, and deprived ones on the other (Kirby, 1982). Inequalities in space manifest as regional problems and derive from geographical unevenness either in the distribution pattern of development, or in the conditions that engender development. Ebenezer (1995) argued that, the factors accounting for regional inequality in Nigeria have social and administrative dimensions and evolved during the ninety-nine years (1861-1960) British colonial rule. The British masters thus, nursed and perpetuated unequal development among the various towns by concentrating development impetus in a few of these towns at the neglect of others.

The recognition of the imbalance in development in the post colonial Nigeria led to deliberate efforts aimed at reducing spatial inequality in the nation's development as contained in the various National Development Plans. (1975-1980). For example, the Second National Development Plan (1970-1974) aptly stated 'a situation where some parts of the country are experiencing rapid growth while other parts are lagging behind can no longer be tolerated' (FGN, 1970). The thrust of the second national development plan therefore, was to establish Nigeria as a united, strong, and self-reliant nation...a just and egalitarian society. The Third and fourth National Development Plans also aimed at 'establishing the country firmly as a just and egalitarian society putting premium on the need to reducing inequalities in inter personal incomes and promoting balanced development among the various communities in the different geographical areas of the country' .

There have been some efforts by government aimed at developing the delta region. Efforts includes the establishment of the Niger Delta Development Board (NDDB) in 1961, Oil Mineral Producing Areas Development Commission (OMPADEC) in 1992, Niger Delta Development Commission (NDDC) in 2000, and the creation of Ministry of Niger Delta in 2008) to enhance the well-being of people in the south-south region. Inspite of these development efforts wide disparities in outcomes persist.

This work is an attempt to $\mathrm{x}$-ray the spatial pattern of development in the south-south region, Nigeria using a factor analytical technique with a view to identifying the factors that mostly account for the variation in 
growth among the LGAs and states in the region. Most studies on spatial pattern of development (e.g Enoh, 1981 and Igwe, 2002) concentrated on individual states in the region. The present work therefore seeks to examine spatial pattern of development focusing on the entire South-South region. More importantly, it sought to examine whether the distribution of these socio-economic amenities among the LGAs in the region are equitable.

\section{Study Location}

The South-South region is defined as comprising the area covered by the natural delta of the Niger River and the areas to the east and west. The natural limits of the Niger River Delta can be defined by its geology and hydrology. Its approximate northern boundaries are located close to the bifurcation of the Niger River at Aboh, while the western and eastern boundaries are around the Benin River and the Imo River, respectively. The area covers approximately 25,900 square kilometers (ERML 1997). Defined in this way, the south-south region consists of six states ( Akwa-Ibom, Bayelsa, Cross River, Delta, Edo, and Rivers).(see fig 1). The region is extremely important, not only to Nigeria, but to the whole world due to its oil reserves and the immense oil wealth. Since the advent of oil exploration over five decades ago, the region has become the breadwinner of the nation, while the region remains the 'sick baby' of the nation (the least developed constituent of the country in physical and socio-economic terms).

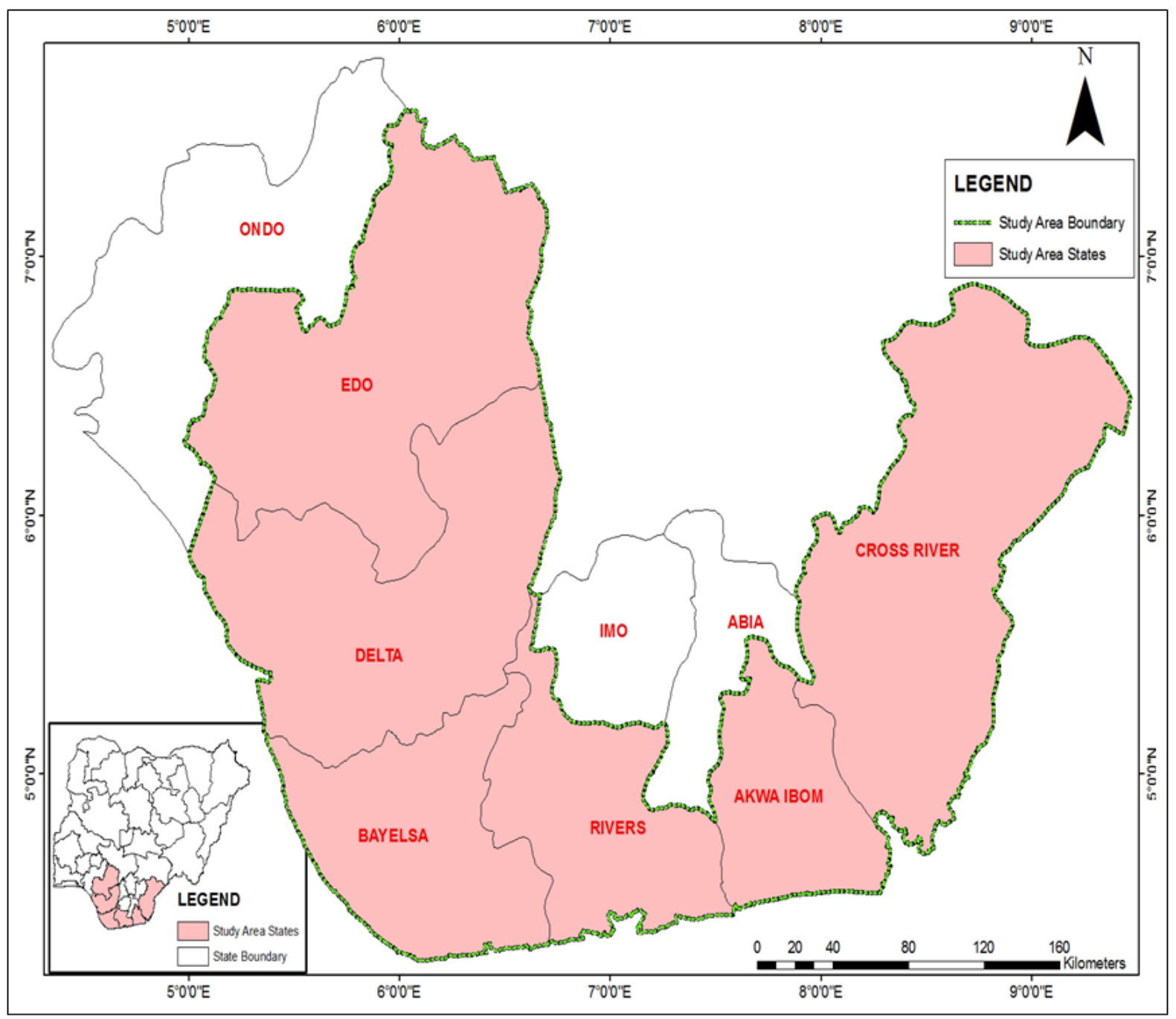

Fig. 1 South-south Administrative Region, Nigeria

\section{Methodology}

The data for this study came from both primary and secondary sources. The primary data was achieved using structured questionnaires. The study area has six states that make up the south-south geo-political region. 
The sampling frame for this study consists of the one hundred and twenty three (123) local government areas of the region. The Niger delta in which the study situates can be broadly classified into two (2) distinct zones viz: the eastern and western delta. Using the stratified simple random sampling technique the study area was divided into the afore mentioned zones eastern delta made up of Akwa-Ibom, Cross-River and Rivers States and western delta comprising of Bayelsa, Delta and Edo states respectively. Thirty percent of states in each zone (that is, one state from each zone) were selected for study. The entire states in each zone were alphabetically arranged and numbered while the table of random numbers was deployed in the selecting the states. The two selected (Bayelsa and Cross River) states have 26 LGAs, and 30\% of the LGAs were again selected across board. That is two LGAs in Bayela state and five LGAs from Cross River State. A sample fraction of 0.005 percent was thereafter taken across board from each selected LGA. Four hundred and thirty six copies of questionnaires were used for the study

Secondary data were also collected from Published government statistics of the different states that make up the study area, Nigeria Year Books, maps, etc. These sources were relied upon mainly to provide data on the selected indicators of development. The development indicators adopted in this work are those considered vital for human well-being and basic amenities needed to support effective living of any community. Fortunately, these indicators meet the socio-psychological needs of man put forward by the Americansociologist, Maslow (1954).

The local government areas served as aerial units of analysis. Analysis at the local government level is based on the believe that, adopting smaller area unit (LGA) in any study such as this, will produce a clearer picture of the existing variation in the socio-economic development among local government areas while the inter-state analysis will further review the aggregate pattern of development among the states in the South-South region

In a study as this, one major snag is that of generating appropriate variables for measuring socioeconomic development. Because 'development' is a nebulous concept, in deciding on its constituents one may run the risk of applying subjective values as to what is, and what is not relevant (Adebisi, 1998). In this study, the choices of socio-economic indices were based on the condition: appropriateness of the variables and the availability of the data covering all the LGAs in the study region.

The selected indicators of development mainly health and educationally related and they include:

- number of maternity centers/“000 population, 2014

- number of hospitals/‘000 population, 2014

- number of doctors/“000 population,2014

- number of doctor/'000 population, 2014

- number of nurses/midwives/‘000 population, 2014

- number of hospital beds/'000 population, 2014

- $\quad$ number of maternity beds/'000 population, 2014

- $\quad$ number of pharmacist/`000 population, 2014

- number of publicly owned primary schools per '000 population; 2014

- number of publicly owned secondary schools per '000 population 2014

- $\quad$ primary school enrolment,2014

- $\quad$ secondary school enrolment, 2014

- $\quad$ number of qualified teacher's to primary school pupils, 2014

- $\quad$ number of qualified teacher's to secondary school pupils; 2014

The calculated Gini-values for all the variables served as data input for the factor analysis. The procedure was used in identifying factors that explain the correlation among a set of variables. Its purpose is to summarize a large number of variables into smaller number of factors. It reduces a set of variables into a smaller set of uncorrelated variables that represents most of the information in the original variables. Table 1 is the list of variables included in the factor analysis. 
Table 1: Variables included in the Factor Analysis

\begin{tabular}{lc}
\hline \multicolumn{1}{c}{ Variable } & Gini-coefficient \\
\hline Number of Hospitals /'000 population & 19.46 \\
Number of Heath centers /'000 population & 20.21 \\
Number of Doctors/'000 population & 49.69 \\
Number of Nurses/Midwives/'000 population & 37.37 \\
Number of Hospital beds/'000 population & 37.83 \\
Number of primary schools/'000 population & 29.06 \\
Number of Secondary school/'000 population & 19.34 \\
Primary school enrolment & 21.93 \\
Secondary school enrolment & 15.22 \\
Number of teachers to primary school pupil's & 18.26 \\
Number of Teachers to secondary school pupil's & 27.83 \\
\hline
\end{tabular}

*Each variable was weighed using the population criterion.

\section{Results}

Using the factor analytical technique, the common characteristics among the 14 variables were identified. In the analysis presented here the factor analysis collapsed 14 variables into 3 orthogonal factors. It is important to observe that all the three factors extracted have eigen-values greater than one and is presented in table 2.

Table 2: Factors and their Eigen-values

\begin{tabular}{|lccc|}
\hline Factors & 1 & 2 & 3 \\
$\begin{array}{l}\text { Eigen-values } \\
\text { \% of Variance accounted } \\
\text { for }\end{array}$ & 2.79 & 1.68 & 1.50 \\
Cumulative (\%) & 25.40 & 15.28 & 13.67 \\
& 25.40 & 40.69 & 54.36 \\
\hline
\end{tabular}

The Eigen-values show the variance explained by each factor. As can be gleaned from table 4.6 above, the first row of the table shows the factors extracted in the factors analysis, the second row represents the total variance explained by each factor while, row three explains the percentage of the total variance attributed to each factor. The total variation explained by the three factors is 54.36 per cent. Factor one accounted for 25.40 per cent of the variance, factor two and three accounts for 15.28 percent and 13.67 percent respectively.

In any factor analysis, only factors with Eigen-values of one and above are extracted for interpretation and further analysis. Arising from the foregoing, the meaning of the result in table 4.16 is that only 54.36 per cent of the total variance is accountable by the three factors while, the remaining 8 factors accounted for 45.64 per cent of the variance. When the three factors are rotated, three factors were obtained (Table 3 ). The table shows how the variables load on each factor. Based on this, 11 variables loaded highly on factor 1 . These variables are number of no of Hospital, number nurses/'000 population, number of midwives/'000 population, number of doctors/'000 population, number of heath center and number of primary school/'000 population. Others are number of teachers to secondary school pupil's, number of teachers to primary school pupils, primary school enrollment, secondary school enrollment, number of secondary schools/'000 population, Given the combination of the variables that loaded highly on factor one; they are better called health factors.

On factor II, number of midwives/'000 population loaded highest (0.692) followed by primary schools enrollment (0.257), no of health centers (0.246), and number of nurses/'000 population ( 0.241$)$. Others are no of Hospitals/'000 population (0.239), no of doctors /'000 population (0.067) and number of primary school teachers /'000 population (0.144). Factor 2 could be better referred to as Literacy factor. The variables that loaded highly in Factor 3: number of teachers to primary school pupil's (0.555), primary school enrollment (0.477), and number of midwives (0.340), number of primary school (0.194), number of secondary school (0.174), and number of doctors $(0,062)$ and could be referred to as education factor. Table 4 is the summary of the variables that loaded highly on each factor and their names. 
Analysis Of Spatial Inequality In Development In The South-South Region, Nigeria: A ...

Table 3: Rotated Component Matrix

\begin{tabular}{|l|l|l|l|}
\hline Variables & Component 1 & 2 & 3 \\
\hline no of Hospital & 0.359 & 0.239 & -0.645 \\
\hline no of Doctors & 0.656 & 0.067 & 0.062 \\
\hline no of Nurses & 0.677 & 0.241 & -0.116 \\
\hline no of heath center & 0.591 & 0.246 & -0.565 \\
\hline no of midwives & 0.161 & 0.692 & 0.34 \\
\hline no of primary school & 0.375 & -0.511 & 0.194 \\
\hline Secondary school teachers & 0.644 & -0.24 & -0.184 \\
\hline secondary school enrollment & 0.238 & -0.644 & -0.018 \\
\hline no primary school teachers & 0.461 & 0.257 & 0.554 \\
\hline primary school enrollment & 0.518 & -0.449 & 0.477 \\
\hline no of secondary school & 0.556 & \\
\hline $\begin{array}{l}\text { Extraction Method: Principal Component Analysis. } \\
\text { Rotation Method: Varimax with Kaiser Normalization. }\end{array}$ \\
\begin{tabular}{l} 
Rotation converged in 4 iterations \\
\hline
\end{tabular} \\
\hline
\end{tabular}

Table 4: Loading of Indicators on each Factor and their Names

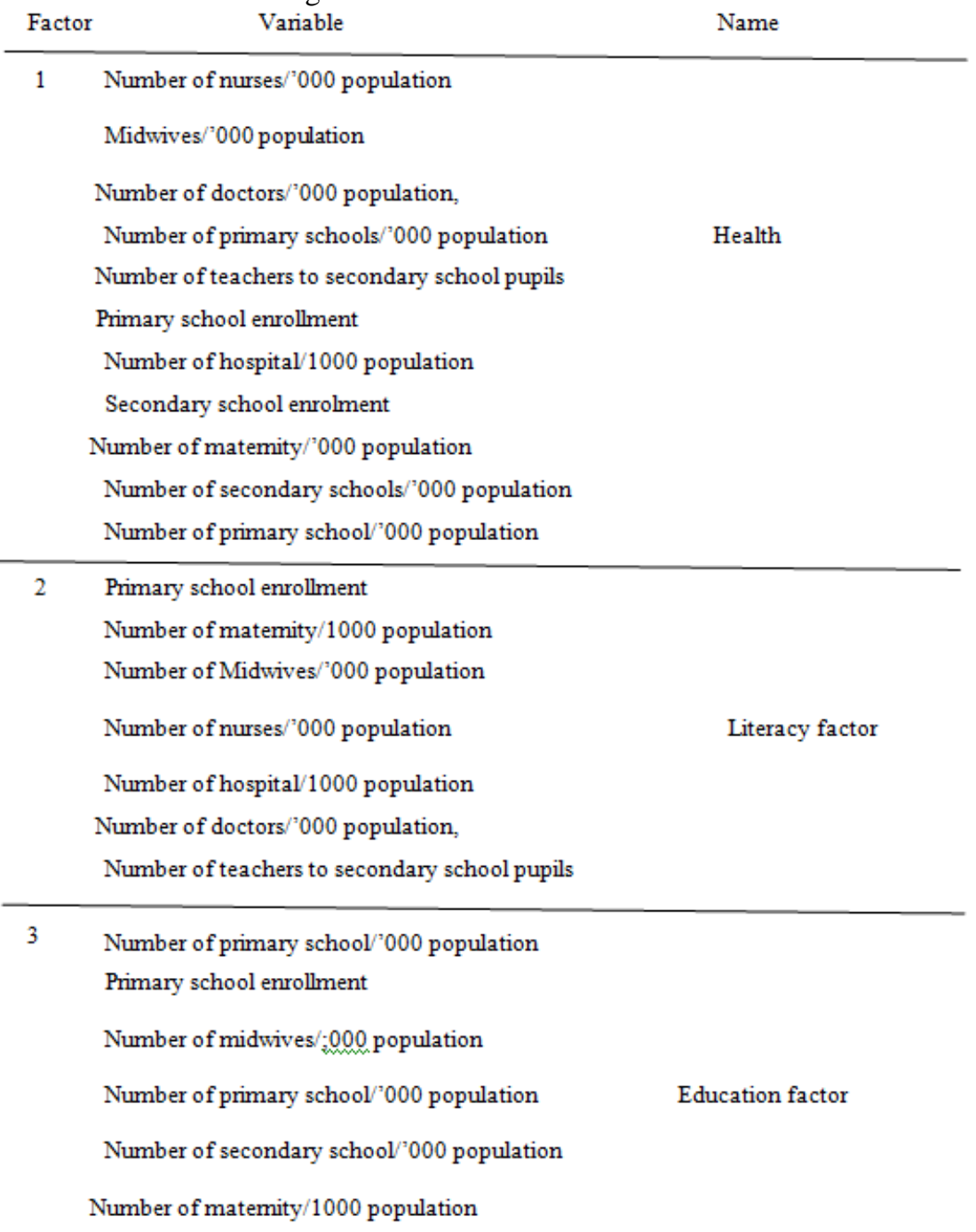

The factor scores indicating the rating of the areas on factors 1-3 is shown in Table 5. The scores of each area on a factor represent the importance of the area with respect to the variables that loaded highly on the original factor. From the Table 5, it is possible to deduce the level of spatial inequality in development among the different local government areas in the study area. The variables with negative scores are regarded as under privileged while areas with positive scores are regarded as privileged in respect to each factor. 
A careful look at factor 1 that represents the health factor reveals that there are eighty-five (85) underprivileged local government areas while the remaining thirty-eight (38) are privileged. Top on the privileged LGAs are port- Harcourt (+6.0), Obio\Apkor (+3.5) Khana (+1.9),Eleme (+1,1), Oredo (+1.1), Calabar south (+1.4), Calabar Municipal (+1.8). The emergence of these Local Government Areas with very high scores further highlight the primate nature of socio-economic development in the study area in respect to the variables under consideration. Fig 2 is the classification emanating from the analysis made on the Health factor.

For factor II, sixty-six (66) areas had negative scores and hence are under privileged while, fifty -even (57) local government areas are privileged. For factor III, sixty-seven (67) local government areas are under privileged with fifty-six (56) privileged LGAs. Figures 3 and 4 depicts the privileged and under privileged local government areas based on their various rating on factor Literacy and Education factors respectively.

Table 5: Scores of LGAs on the Factors

\begin{tabular}{|c|c|c|c|}
\hline LGA & Factor 1 & Factor 2 & Factor 3 \\
\hline & -0.09044 & -0.38875 & .15441 \\
\hline Abak & -0.0052 & -.00543 & -6544 \\
\hline Eastern Obolo & 0.2546 & -0.40722 & -0.59386 \\
\hline Eket & -0.43205 & 0.13604 & 0.2442 \\
\hline Esit-Eket & -0.43662 & -0.2292 & 0.3635 \\
\hline Essien Udim & -0.84007 & 0.11406 & 0.11738 \\
\hline Etim-Ekpo & -0.52912 & 0.34336 & -0.24783 \\
\hline Etinan & -0.25738 & -0.4239 & 0.29026 \\
\hline Ibeno & -0.68704 & 0.22244 & -0.1655 \\
\hline Ibesikpo-Asutan & -0.68704 & 0.22244 & -0.1655 \\
\hline Ibesikpo-Asutan & -0.23704 & -0.73861 & -0.53128 \\
\hline Ibiono-Ibom & -0.09044 & -0.38875 & 1.15441 \\
\hline Ika-Annang & -0.16783 & -0.02972 & 0.37183 \\
\hline Ikono & -0.34549 & -0.52129 & 0.58456 \\
\hline Ikot Abasi & 0.81012 & 0.75232 & -0.17711 \\
\hline Ikot Ekpene & 0.53588 & -1.63997 & -0.91979 \\
\hline Ini & -0.00233 & -0.29136 & 0.86011 \\
\hline Itu & 0.53588 & -1.63997 & -0.91979 \\
\hline Mbo & -0.25738 & -0.4239 & 0.29026 \\
\hline Mkpat-Enin & -0.95149 & 0.04811 & 0.15284 \\
\hline Nsit-Atai & -0.42805 & -0.1655 & -0.84796 \\
\hline Nsit-Ibom & -0.43662 & -0.2292 & 0.3635 \\
\hline Nsit-Ubium & 0.47049 & 1.73298 & -1.56953 \\
\hline Obot-Akara & -0.95149 & 0.04811 & 0.15284 \\
\hline Okobo & -0.45979 & -0.3156 & 0.66922 \\
\hline Onna & -0.2172 & 0.18696 & 0.46791 \\
\hline Oron & -0.01656 & -1.16195 & 0.24921 \\
\hline Oruk Anam & -0.42805 & -0.1655 & -0.84796 \\
\hline Ukanafun & & & \\
\hline
\end{tabular}


Analysis Of Spatial Inequality In Development In The South-South Region, Nigeria: A ...

Table 5: Scores of LGAs on the Factors (Contd)

\begin{tabular}{|c|c|c|c|}
\hline LGA & Factor 1 & Factor 2 & Factor 3 \\
\hline Udung-Uko & -0.42805 & -0.1655 & -0.84796 \\
\hline Uruan & -0.43662 & -0.2292 & 0.3635 \\
\hline Urue-Offong/Oruko & -0.905 & 0.10307 & 0.10596 \\
\hline Uyo & -0.00111 & 0.94351 & -0.48066 \\
\hline Brass & -0.42805 & -0.1655 & -0.84796 \\
\hline Ekeremor & 1.04999 & -0.48066 & -0.42805 \\
\hline Kolokuma/Opokuma & 0.94351 & -0.03363 & -2.04663 \\
\hline Ogbia & 0.53588 & -1.63997 & -0.91979 \\
\hline Sabama & 1.60733 & 0.23173 & -1.89533 \\
\hline Southern Ijaw & 1.04999 & -0.51875 & -1.67102 \\
\hline Yenegoa & 1.71427 & -1.82848 & -0.70921 \\
\hline Abi & -0.48066 & 0.97123 & 0.03238 \\
\hline Akamkpa & 0.47049 & 1.73298 & -1.56953 \\
\hline Akpabuyo & 2.1113 & 2.22669 & 1.27003 \\
\hline Bakassi & -0.42805 & -0.1655 & -0.84796 \\
\hline Bekwarra & 0.53326 & 0.01158 & -0.84796 \\
\hline Biase & -0.59332 & 1.42184 & 0.84089 \\
\hline Boki & -0.42805 & -0.1655 & -0.84796 \\
\hline Calabar municipal & 1.80251 & 4.08471 & 2.04848 \\
\hline Calabar South & 1.41834 & 3.05221 & 2.66131 \\
\hline Bomadi & -0.55422 & -0.22231 & 0.25514 \\
\hline Burutu & -0.29057 & -0.80227 & -0.24467 \\
\hline Ethiope East & -0.89119 & -0.52508 & 0.1234 \\
\hline Ethiope West & -0.51246 & -0.29772 & 0.57228 \\
\hline Ika North East & -0.42805 & -0.1655 & -0.84796 \\
\hline Ika South & -0.321 & -0.4343 & 0.37699 \\
\hline Isoko North & -0.61452 & 0.35088 & 0.28457 \\
\hline Isoko South & -0.21038 & -1.12264 & 0.16007 \\
\hline Ndokwa East & -0.14011 & -0.66258 & -.13992 \\
\hline
\end{tabular}

Table 5: Scores of LGAs on the Factors (Contd)

\begin{tabular}{|c|c|c|c|}
\hline LGA & Factor 1 & Factor 2 & Factor 3 \\
\hline Ndokwa West & -0.4436 & -0.91065 & 0.03821 \\
\hline Okpe & -0.58112 & -1.22699 & 0.42044 \\
\hline Oshimili North & -0.92832 & 0.13451 & -.15288 \\
\hline Oshimili South & -0.22263 & -1.04806 & -.46124 \\
\hline Patani & -1.01643 & 0.03712 & 0.14142 \\
\hline Sapele & 0.09843 & -1.28606 & -.33972 \\
\hline $\mathrm{Udu}$ & -0.42805 & -0.1655 & -.84796 \\
\hline Ughelli North & -0.19831 & -0.01207 & -.23891 \\
\hline Ughelli South & -0.73816 & -0.4167 & -.15948 \\
\hline Ukwuani & -0.70631 & 0.28832 & -.54706 \\
\hline Uvwie & -0.28756 & -1.05905 & -.47266 \\
\hline Warri North & -0.1298 & -0.69428 & 0.47567 \\
\hline Warri South & 0.98336 & -0.35989 & -.73375 \\
\hline Warri South West & -0.46677 & -0.99705 & 0.34394 \\
\hline Akoko-Edo & -0.53011 & 0.4831 & -.13567 \\
\hline Egor & -0.3539 & 0.67788 & -.72427 \\
\hline Esan Central & -0.92832 & 0.13451 & -.15288 \\
\hline Esan North. East & -0.70631 & 0.28832 & -.54706 \\
\hline Esan South East & -0.70631 & 0.28832 & -.54706 \\
\hline Esan West & -0.70631 & 0.28832 & -.54706 \\
\hline Etsako Central & -0.92832 & 0.13451 & -.15288 \\
\hline Etsako East & -0.61821 & 0.38571 & -.84136 \\
\hline Etsako West & -0.70631 & 0.28832 & 0.54706 \\
\hline Igueben & -1.01643 & 0.03712 & 0.14142 \\
\hline Ikpoba-Okha & -0.70631 & 0.28832 & 0.54706 \\
\hline Oredo & 1.19666 & 1.9339 & 5.16667 \\
\hline Orhionmwon & -0.61821 & 0.38571 & 0.84136 \\
\hline Ovia NorthEast & -0.84022 & 0.2319 & -0.4719 \\
\hline Ovia SouthWest & -0.84022 & 0.2319 & -.44719 \\
\hline
\end{tabular}


Analysis Of Spatial Inequality In Development In The South-South Region, Nigeria: A ...

Table 5: Scores of LGAs on the Factors (Contd)

\begin{tabular}{|c|c|c|c|}
\hline LGA & Factor 1 & Factor2 & Factor 3 \\
\hline Owan East & -0.92832 & 0.13451 & -.15288 \\
\hline Owan West & -0.79442 & 0.19093 & -.25276 \\
\hline Uhunmwode & -0.84022 & 0.2319 & -.44719 \\
\hline ABUALIODUAL & 0.37977 & 0.34684 & 0.5547 \\
\hline AHOADA EAST & -3334 & -.77728 & -.08569 \\
\hline AHOADA WEST & 0.0304 & -0.281 & 0.23077 \\
\hline AKUKU-TORU & 0.01481 & -.24996 & 0.97514 \\
\hline ANDONI & 0.44636 & 0.4277 & -.58437 \\
\hline ASARI-TORU & -0.03038 & 0.1097 & 0.83332 \\
\hline BONNY & 0.56576 & -0.8695 & 0.98897 \\
\hline DEGAMA & 0.048 & 0.19694 & 0.16616 \\
\hline ELEME & 1.1741 & 3.23281 & 2.42897 \\
\hline EMOHUA & 0.78781 & 1.49188 & 0.73658 \\
\hline ETCHE & 0.86 & 0.01365 & 0.84863 \\
\hline GOKANA & -0.21865 & 0.10983 & 0.09204 \\
\hline IKWERRE & 0.014 & 1.00425 & 0.79367 \\
\hline GOKANA & -0.21865 & 0.10983 & 0.09204 \\
\hline KHANA & 1.96929 & 1.00399 & 2.81424 \\
\hline OBIO\APKOR & 3.51445 & 2.21164 & -0.8176 \\
\hline OGBAIEGBEMAINDONI & -0.46597 & 0.24276 & 0.52541 \\
\hline OGU\BOLO & -0.22926 & 0.57468 & 0.37139 \\
\hline OKIRIKA & 0.57298 & 0.54766 & 0.53123 \\
\hline OMUMA & -0.20839 & 0.32253 & 0.01771 \\
\hline OPOPOINKORO & 0.78777 & 0.71568 & 0.59479 \\
\hline OYIBO & -0.17908 & 0.5948 & 0.70768 \\
\hline PORT HARCOURT & 6.00878 & -.02827 & -.53982 \\
\hline TAI & 0.5914 & 0.16709 & 1.30945 \\
\hline
\end{tabular}

Source: Authors 'Computer Print Analysis, 2014.

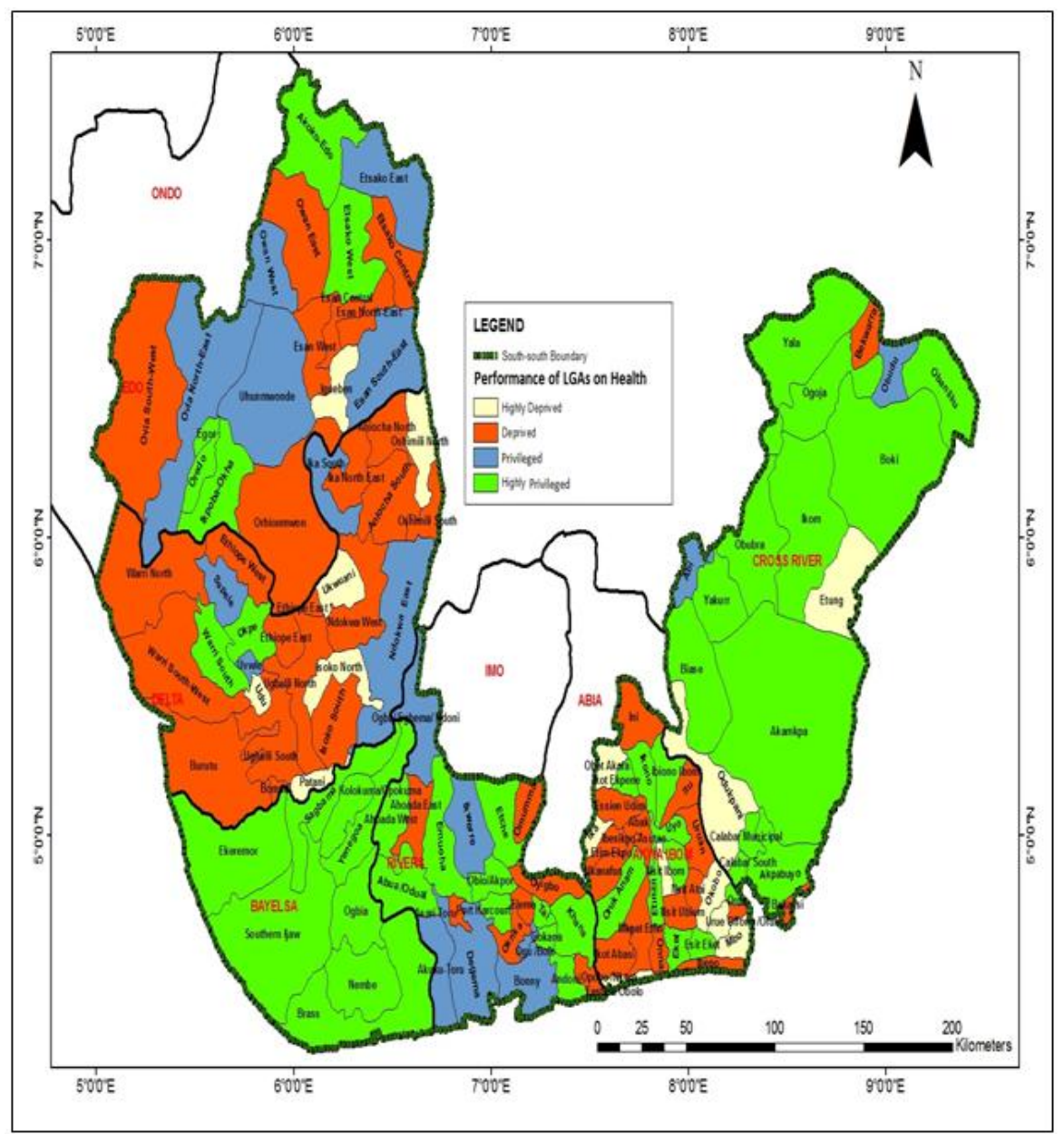

Fig.2: Privileged and Deprived LGAs of South -South in Health Dimension of Spatial Inequality Source: Researchers' Analysis (see Table 5). 


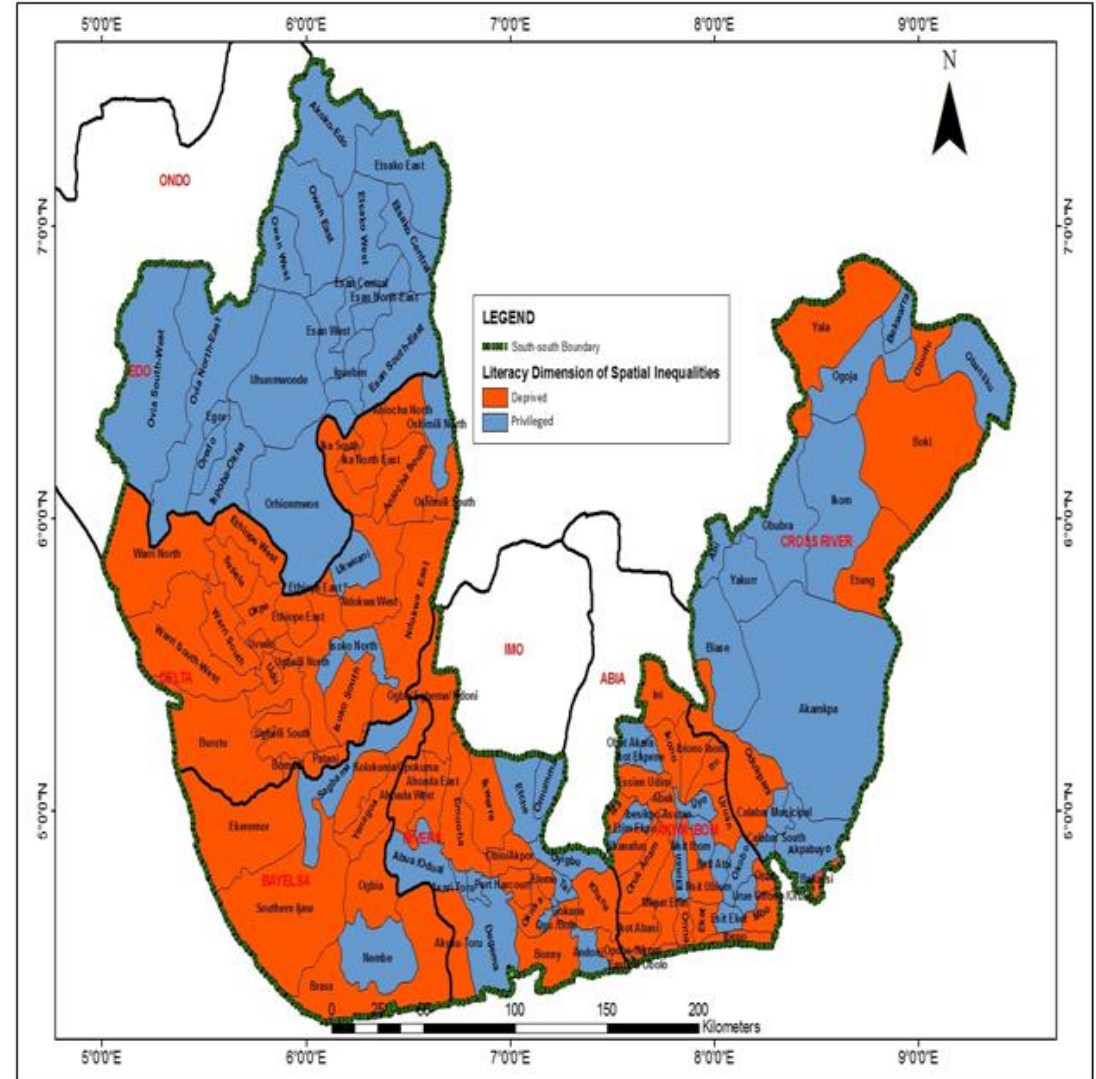

Fig.3: Privileged and Deprived LGAs of South-South in Literacy Dimension of Spatial Inequality. Source: Researchers' Analysis (see Table 5).

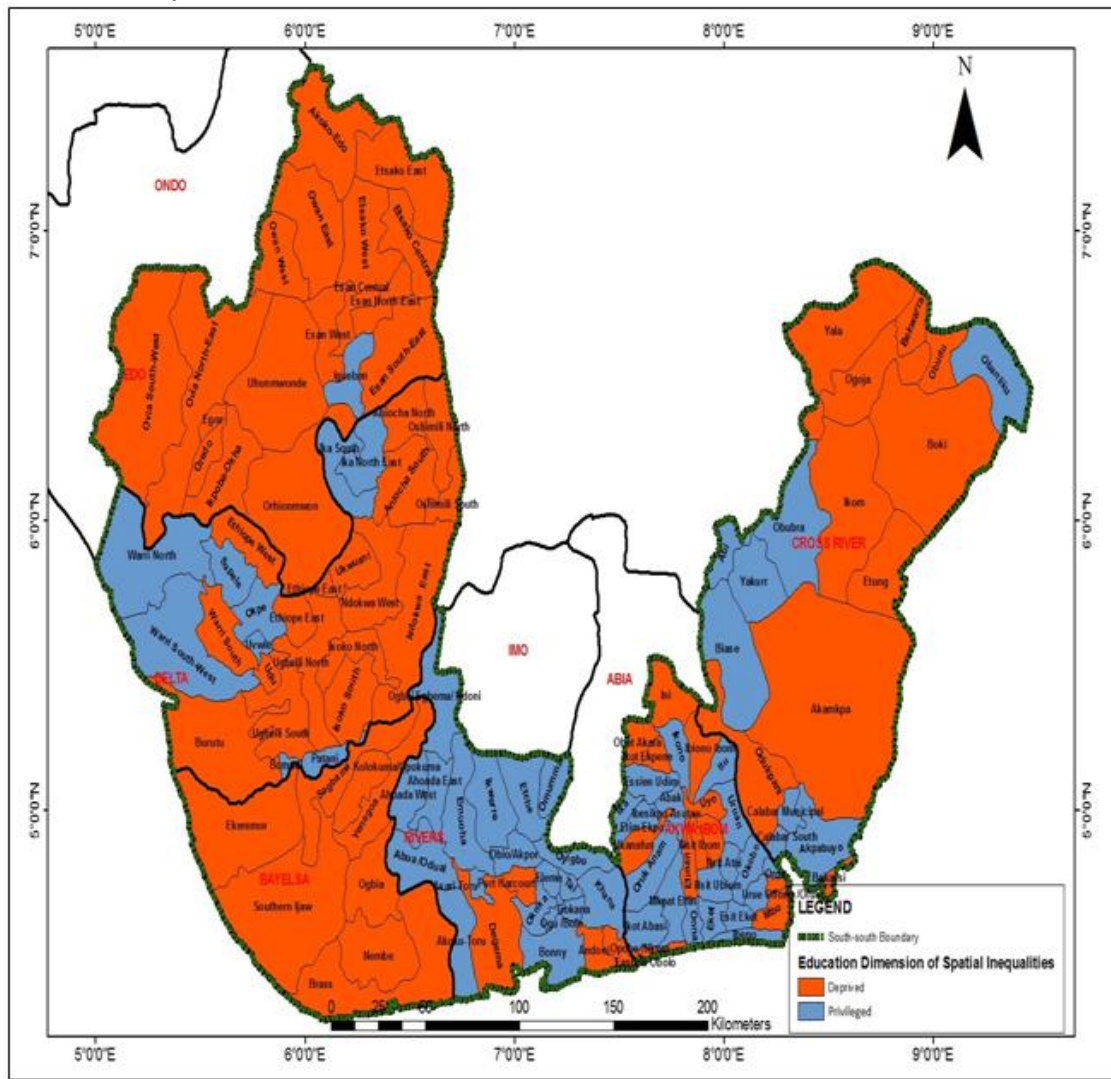

Fig.4: Privileged and Deprived LGAs of South-South in Education Dimension of Spatial Inequality Source: Researchers’ Analysis (see Table 5). 


\section{Discussion and Conclusion}

An important remark that could be made in the analysis made in this section is that LGAs with negative scores in any variable is considered deprived while those with positive scores are privileged. Thus, the level of deprivation varies according to the number of negative scores of an LGA in each factor. Accordingly six (6) Local Government Areas of Abuai/Odua, Tai, Akpabuyo, Calabar-Municipal, Etche, and Calabar-south had positive scores in the three factors and could be said to be privileged in all the factors. While a few Local Government Areas had negative scores in two factors others had negative scores in all the three factors. Also important from the foregoing is that, some areas had high positive scores in several factors, which is also an indication of its privileged status. Similarly, most of the local government areas have very low negative scores in most of their scores indicative of their level of under-privileged position.

One of the intriguing aspects of socio-economic development in the south-south region is that, while some development is taking place, they are unevenly distributed among the different Local Government Areas and States in the region. This phenomenon has led to polarization of development, producing privileged areas on one hand, and under privileged areas on the other. This phenomenon points to the fact that within any space economy of a developing country, State or region, there is the tendency for local areas within a relatively small region to be grossly unequal in terms of the distribution of socio-economic or development facilities available to the people.

Using some selected indicators of development, the study uncovered that there exists both privileged and deprived LGAs in the space economy of south-south in terms of the distribution of health and educational facilities. Three factors of health, literacy and education were implicated as key factors accounting for the variation in development in the study area. It therefore suggested that for effective regional development, the deprived areas (rural) must be effectively incorporated into the privileged areas (urban centers). There should be a well thought out sub-urbanization programme aimed at engendering growth in the lagging areas of southsouth. This can be achieved by increasing information flow, providing other socio-economic facilities like roads, health care services, and educational facilities through the process of integrated rural development planning. Public investment would play a critical role not just in overcoming immediate disadvantage.

Private participation in the provision of health and educational facilities is imperative as way to bring about convergence in inequality in the area. Good investment climate that will encourage private participation in public facility provision is recommended. There is also the need to integrate both economic and regional planning into the overall planning efforts of the states with a view to ensuring that all aspects of human needs are taken into consideration during any planning endeavour.

\section{Funding Information}

The authors have no support or funding to report.

\section{Conflict of Interest}

There is no conflict of interest.

\section{Authors Contributions}

All authors equally contributed in this work.

\section{Ethics}

This article is original and contains unpublished material. All authors read and approved the manuscript, and no ethical issues involved.

\section{References}

[1]. Adebisi, A., 1998. Development Trends and Intra-regional Inequalities in Ogun State, Nigeria International Journal of Urban Affairs Volume 2 Number 2, pp.1-8.

[2]. Bhagwati, I. J., 1971. Economics of Underdeveloped Countries. Werden, Fold and Nicholson.

[3]. Ebenezer, A., 1995. Regional Inequalities in the Process of Nigeria's Development: Socio-political and Administrative Perspective. Journal of Social Development. Vol. 10(2) pp61-80

[4]. Enoh, C.E.O., 1981. Spatial Inequalities in the Socio-economic Development of Cross River State, PhD Thesis, Kent State University.

[5]. Federal Republic of Nigeria, 1970. Second National Development Plan (1970-1974) Lagos.

[6]. Federal Republic of Nigeria, 1975. Third National Development Plan (1975-1980) Lagos. The Central Planning Office, Federal Ministry of Economic Development pp29-31.

[7]. Igwe, C.F., 2002. An Analysis of Duality in the Space Economy of Rivers State, Nigeria. Unpublished PhD Thesis, University of Port Harcourt, Port-Harcourt, Nigeria. 
[8]. Kirby, A.M., 1982. The Politics of Location: An Introduction. London, Methuen \& co pp1-95

[9]. Mabogunje, A., 1980. The Development Process: A Spatial Perspective. Hutchinson, London.

[10]. Maslow, A. H., 1954. Motivation and Personality. New York, Harpes 